\section{A Comparison of Airblast and Air Assisted Rotary Atomizer Spray Technologies in Peach Production}

\author{
Charles C. Reilly ${ }^{1}$, \\ Kathryn C. Taylor ${ }^{2,3}$, and \\ Michael W. Hotchkiss ${ }^{1}$
}

AdDitional INDEX wORDs. controlled droplet atomizer, disease and pest control, off-target spray movement, pesticide application, pesticide drift, Proptec, Prunus persica, sprayer

SumMary. Pesticide application in peach (Prunus persica) orchards with a commercial airblast sprayer was compared to that of an air assisted rotary atomizer (AARA), low-volume sprayer during the 2000 through 2003 seasons. The two technologies were employed during early season petal fall applications, shuck split applications and standard cover sprays using phosmet, sulfur, propiconazole, chlorothalonil, azoxystrobin and captan. Ripe fruit, picked 1 day prior to first harvest each season were rated for peach scab (Cladosporium carpophilum), brown rot (Monilinia fructicola), insect (Hemipteran) damage (cat facing), and blemishes. Differences in brown rot, insect damage, and blemish ratings were not detected between the treatments for each of the four seasons. Differences were detected during the 2000 and 2001 seasons for peach scab, with the AARA sprayer plots having a higher incidence. Spray coverage was quantitatively evaluated with Rhodamine $B$ dye by leaf rinses that indicated there was equivalent coverage for each application method. Phosmet residue detection on trees of the treated rows was also equivalent from each method. Phosmet off-target spray movement (drift) was reduced $59 \%$ one row away from the treated row and $93 \%$ in the fifth row from the treated row by the AARA sprayer compared to airblast sprayer drift.

${ }^{1}$ USDA-ARS, Southeastern Fruit and Tree Nut Research Laboratory, 21 Dunbar Rd., Byron, GA 31008

${ }^{2}$ Horticulture Department, University of Georgia, 21 Dunbar Rd., Byron, GA 31008

${ }^{3}$ To whom reprint requests should be addressed; e-mail: kctaylor@uga.edu
Stone fruit production is second only to peanuts (Arachishypogaea) in the use of pesticides in the southeastern United States, with pecan (Carya illinoinensis) production third (Littrell and Bertrand, 1981). Concerns for perceived negative impacts on the environment are always present, especially for pesticide off-target spray movement (drift) during application. Excessive drift can occur with routine cover sprays during fruit maturation but is the most severe during the windy conditions of March and April when bloom sprays are applied.

The airblast sprayer, the current technology employed by the stone fruit industry for pesticide application, has been used for 60 years (Barrat et al., 1982). A typical tractor-towed unit is powered by the tractor power-take-off to run the circulating and pressure pumps and the air fan. Pesticides are typically delivered at a rate of 467.7 $\mathrm{L} \cdot \mathrm{ha}^{-1}$ (50 gal/acre) and dispersed as fine droplets $[\sim 333-\mu \mathrm{m}(0.013$ inch $)$, volume median diameter] by using high-pressure nozzles mounted around a high-speed fan (Barrat et al., 1981; Ledebuhr et al., 1986).

Recently, newer technologies are being explored to reduce spray drift and the environmental impact of orchard operations. During the last decade, hydraulic nozzles or controlled droplet atomizers (CDA) (VanEe et al., 2000) were employed to reduce droplet size, and air assistance was added to direct these smaller droplets as needed into the tree canopy in the rotary atomizer design of tunnel sprayers for dwarf fruit tree plantings (Doruchouski, 1993; Peterson and Hogmire, 1994). That technology was modified somewhat to develop an over-tree version of the air assisted rotary atomizer (AARA). With this configuration of CDA, fine droplets $[\sim 120-\mu \mathrm{m}(0.005$ inch $)$, volume median diameter] are projected downward with the assistance of propellers that push the atomized spray solution into the tree canopy at velocities of as much as $96.6 \mathrm{~km} \cdot \mathrm{h}^{-1}$ (60 mph) (Ledebuhr, 2000).

Like airblast technology, the CDA configuration of AARA technology uses the tractor's power-take-off to power the hydraulic pump that in turn operates the mixing and peristaltic pumps, as well as the hydraulic cylinders that operate a T-boom system and the rotary atomizers of the spray heads. The 8.5-m (28 ft) T-boom allows for over-the-row spray application of two complete rows of peach trees in a single pass. The vertical range of the $\mathrm{T}$-boom is 1.5 to $5.2 \mathrm{~m}$ ( 5 to $17 \mathrm{ft}$ ) above the ground, adjusting to varying tree heights. Each side of the boom initially had three rotary atomizers for pesticide delivery, but an additional atomizer was added to increase efficiency of coverage in the last year of the trial. In grape (Vitisspp.) vines using the rotary atomizer technology, at equivalent concentration, pesticides applied at a rate of $280.6 \mathrm{~L} \cdot \mathrm{ha}^{-1}$ (30 gal/acre) had better efficacy than airblast application of pesticides at a rate of $467.7 \mathrm{~L} \cdot \mathrm{ha}^{-1}$ (Landers et al., 2000).

A potential risk in using a new technology of lower pressure or volume pesticide application is that treatment efficacy may be diminished compared to the standard spray technology. In addition, a change in droplet deposition may alter the frequency of fruit blemishes, discolorations, or inking associated with certain pesticides (Cheng and Crisosto, 1994). In contrast, reductions in the occurrence of peel blemishes, and disease or pest damage can improve fruit grade (USDA, 1995 ) and, ultimately, profitability.

Our primary objectives were to: 1) assess the performance of a lowvolume spray technology, AARA, and a high-volume spray technology, the standard airblast sprayer; and 2) make adjustments as needed to optimize the AARA for use in a peach orchard setting. Peach harvest was assessed for disease incidence of brown rot and peach scab, insect (Hemipteran) damage, and peel blemish, as measures of sprayer efficacy. In addition, spray coverage and pesticide drift were quantified.

\section{Materials and methods}

Field experiments. Non-irrigated blocks of 2.63 ha $(6.5$ acre $)$ containing 6-year-old peach 'Sunprince' and 11-year-old 'Redglobe' at $6.1 \times 6.1 \mathrm{~m}(20 \mathrm{ft})$ spacing with 72 trees per row, were managed as recommended in the 2000 through 2003 Southern Peach, Nectarine and Plum Pest Management and Culture Guides [University of Georgia, Cooperative Extension Service (UGA-CES), 2003]. Spray management primarily directed applications toward scab, brown rot, and Hemipteran (cat facing) insect management. The fungicides, sulfur (Micro Flo Co., Memphis, Tenn.), chlorothalonil (Bravo; Syngenta Crop 
Protection, Wilmington, Del.), captan (Micro Flo Co.), propiconazole (Orbit; Syngenta Crop Protection), and azoxystrobin (Abound; Syngenta Crop Protection); and insecticide phosmet (Imidan; Gowan Co., Yuma, Ariz.) were applied following the Southern Peach, Nectarine and Plum Pest Management and Culture Guide (UGA-CES, 2003). The AARA unit was calibrated to deliver $280.6 \mathrm{~L} \cdot \mathrm{ha}^{-1}$ at $8.0 \mathrm{~km} \cdot \mathrm{h}^{-1}(5 \mathrm{mph})$ and the airblast sprayer calibrated to deliver 467.7 $\mathrm{L} \cdot \mathrm{ha}^{-1}$ at $3.2 \mathrm{~km} \cdot \mathrm{h}^{-1}(2 \mathrm{mph})$. The rate per unit area of each material applied per application method is given in Table 1 .

The orchards were divided into four paired blocks consisting of six rows each for treatment by the airblast sprayer and 12 rows each for treatment by the rotary atomizer sprayer. The study was conducted during the 2000 through 2003 growing seasons. All treatments were applied on the same days throughout each season. The first sprays, at shuck split, were made on 13 Mar. 2000, 7 Mar. 2001, 27 Mar. 2002, and 19 Mar. 2003. Cover spray applications began 26 Apr. 2000, 20 Apr. 2001, 26Apr. 2002, 14 Apr. 2003, and continued through and included preharvest sprays, ending on 11 July 2000 and 7 July 2001, 1 July 2002, and 3 July 2003 . The 2000 season required 11 cover spray pesticide applications vs. 14 applications in 2001. The 2002 and 2003 seasons required seven and 11 pesticide applications, respectively. For all analyzed data, means were separated by Duncan's multiple-range test (Little and Hills, 1978).

Fruit samples were taken $1 \mathrm{~d}$ before the first commercial harvest (12 July 2000, 11 July 2001, 3 July 2002 , and 6 July 2003) by randomly removing 80 fruit from the middle one-third of the two middle rows in each treatment block. Fruit taken for each sample were selected randomly from the outer middle-third of the canopy at a height of $\sim 1.5$ to $2.1 \mathrm{~m}$ ( 5 to $7 \mathrm{ft}$ ). The samples were rated for Hemipteran insect damage, blemishes and scab incidence for the four seasons and severity in 2003. Scab severity was rated using a scale: $1=$ no scab; $2=$ 1-25 lesions; $3=26-50$ lesions; $4=$ $5 \mathrm{l}-100$ lesions; $5=$ greater than 100 lesions. The fruits were then stored at room temperature for $7 \mathrm{~d}$ on cardboard trays in apple boxes and after $7 \mathrm{~d}$ rated for brown rot incidence.

Table 1 . The rate of each pesticide reported as $100 \%$ and $80 \%$ of the rates recommended for southeastern peach management.

\begin{tabular}{lccc}
\hline Material & \multicolumn{2}{c}{$\mathbf{1 0 0 \%}$} & $\mathbf{8 0 \%}$ \\
\hline Sulfur $\left[\mathrm{kg} \cdot \mathrm{ha}^{-1}(\mathrm{lb} / \mathrm{acre})\right]$ & 10.1 & $(9)$ & $7.8(7)$ \\
Chlorothalonil $\left[\mathrm{L} \cdot \mathrm{ha}{ }^{-1}(\mathrm{pt} / \mathrm{acre})\right]$ & $4.09(3.5)$ & $3.27(2.8)$ \\
Captan $\left[\mathrm{kg} \cdot \mathrm{ha}^{-1}(\mathrm{lb} / \mathrm{acre})\right]$ & $7.62(6.8)$ & $6.16(5.5)$ \\
Propiconazole $\left[\mathrm{g} \cdot \mathrm{ha}^{-1}(\mathrm{oz} / \mathrm{acre})\right]$ & 119.1 & $(1.7)$ & $98.1(1.4)$ \\
Azoxystrobin $\left[\mathrm{g} \cdot \mathrm{ha}^{-1}(\mathrm{oz} / \mathrm{acre})\right]$ & 252.2 & $(3.6)$ & $196.1(2.8)$ \\
Phosmet $\left[\mathrm{kg} \cdot \mathrm{ha}^{-1}(\mathrm{lb} / \mathrm{acre})\right]$ & 2.2 & $(2)$ & $1.79(1.6)$ \\
\hline
\end{tabular}

SPRAY COVERAGE AND OFF-TARGET SPRAY MOVEMENT. Spray coverage and off-target movement (drift) were measured two ways: 1 ) by comparing the total amount of Rhodamine B on leaf surfaces inside and on the outside of trees with a full leaf crop; and 2) by assessing the level of the pesticide phosmet in a full canopy when spray application was made on trees that had not received phosmet application for 7 weeks.

Rhodamine B was applied by airblast or AARA sprayer at a concentration of $250 \mu \mathrm{g} \cdot \mathrm{mL}^{-1}$ (ppm) to assess spray coverage. Wind velocity varied from 7.24 to $9.7 \mathrm{~km} \cdot \mathrm{h}^{-1}$ ( 4.5 to $6 \mathrm{mph}$ ) at the time of application by either method. Application was made late the afternoon of 15 Aug. 2000 $(\sim 1600 \mathrm{HR})$. The morning after application $(\sim 0800 \mathrm{HR}), 10$ fully expanded leaves were collected at a height of 1.2 to $1.8 \mathrm{~m}$ (4 to $6 \mathrm{ft}$ ) from the inside area $[0.6-\mathrm{m}(2 \mathrm{ft})$ radius around the central axis] and 10 leaves from the outside surface of the canopy of each of 10 treated trees per sprayer treatment. Using a modification of the method described by Chiba (1974), leaf discs were assessed for Rhodamine B spray deposition. Six leaf discs were taken from each leaf with a $1.3-\mathrm{cm}$-diameter ( $0.5 \mathrm{l}$ inch) cork borer by removing two discs from each half of the leafblade and two crossing the midrib. A determination of Rhodamine B on leaf surfaces was made by rinsing each six-disc leaf sample by shaking on a rotary shaker for $90 \mathrm{~min}$ in $1 \mathrm{~mL}$ of $1.5 \mathrm{~N}$ sodium hydroxide $(\mathrm{NaOH})$. Discs were then removed and samples were maintained in the dark until spectrophotometric determinations were made within 4 d. Spray distribution was determined by measuring the absorbance at 460 $\mathrm{nm}\left(\mathrm{A}_{460 \mathrm{~nm}}\right)$ by spectrophotometry of the eluted dye obtained from the leaf discs.

During 2001, 7 weeks after the last pesticide application was made on the 'Sunprince' trees, a phosmet application was made to determine spray drift. Six weeks after the last phosmet application, three 20-leaf samples were randomly taken throughout the orchard ( 1 week prior to the drift study), and it was determined that the orchard was free of phosmet [all samples were in the non-detectable range for the analysis, $\left.<5 \mathrm{ng} \cdot \mathrm{g}^{-1}(\mathrm{ppb})\right]$. The following week, drift from each application method was compared by applying phosmet at $2.2 \mathrm{~kg} \cdot \mathrm{ha}^{-1}$ (2 lb/acre) with the airblast and $1.79 \mathrm{~kg} \cdot \mathrm{ha}^{-1}(1.6$ $\mathrm{lb} /$ acre $)(80 \%$ of airblast rate) with the AARA sprayer. Wind velocity varied from 4.8 to $8.0 \mathrm{~km} \cdot \mathrm{h}^{-1}$ ( 3 to $5 \mathrm{mph}$ ) at the time of application by either method. One day after application, three leaf samples (80 leaves/sample) were collected at a height of 1.3 to 1.6 $\mathrm{m}(4.25$ to $5.25 \mathrm{ft})$. Trees were sampled from the treatment row and the first, third, and fifth adjacent down-wind rows from the treatment row for pesticide analysis. Control samples were collected within the same orchard from trees that had not received phosmet treatment, 20 rows up-wind from the treated trees.

Pesticide analysis. Leaf samples were submitted to the Agricultural Services Laboratory, University of Georgia, for phosmet analysis. Pesticide residues were extracted with ethyl acetate, cleaned by gel permeation chromatography, and analyzed using a Trametrics 9001 gas chromatograph (GC) with attached N-P detector (Austin, Texas). Positive pesticide residues were confirmed by GC-Mass Spectroscopy. The GC columns utilized were a SPB-5 or a SPB-35 megabore capillary column (30-m length). The column oven was temperature-programmed with an initial temperature of $135^{\circ} \mathrm{C}$, held for $1 \mathrm{~min}$, followed by a programmed temperature increase to $275^{\circ} \mathrm{C}$ at $5^{\circ} \mathrm{C}$ per min. The final temperature was held for $5 \mathrm{~min}$. A fortified sample and reagent blank were 
included with each set of analyses with GC grade standards for fortification and GC quantification (Accustandard, New Haven, Conn.). The phosmet fortification level was $0.25 \mu \mathrm{g} \cdot \mathrm{g}^{-1}(\mathrm{ppm})$ and its mean recovery was $97.8 \%$. No attempt was made to determine metabolites or breakdown products. Pesticide residues were determined by a general non-ionic screening adapted from the Food and Drug Administration Pesticide Analytical Manual [U.S. Food and Drug Administration (USFDA), 2002]. Reported residue levels were not corrected for percent recovery.

\section{Results and discussion}

We found there was no difference in damage from cat facing insects in plots treated with the airblast or AARA sprayer in all 4 years of the trial (Table $2)$. Fruit blemish was also measured for the four seasons (Table 2). The ratings indicated no difference for 2000-03. During the 2001 season, the blemish ratings for both AARA and airblast treatments were much greater than the other three seasons. The 'Sunprince' orchard was struck by a hailstorm on 12 May 2001 and this caused noticeable damage to the fruit that most likely increased and influenced the 2001 blemish ratings for both spray treatments. The incidence of postharvest brown rot was no different for the four seasons comparing the two spray systems (Table 2 ).

Differences were detected during the 2000 and 2001 seasons for peach scab incidence, with the AARA sprayer plots having a higher incidence (Table 2). We suspected that reduced scab control may have been related to the reduced (20\% less) sulfur applied, an amount below the recommended level (2003), with the AARA sprayer in those years. Therefore, in years 2002 and $2003,100 \%$ of the recommended rate applications were made with the AARA sprayer. In 2002 and 2003 seasons, scab incidence was similar in airblast and AARA treatments. Further, because precipitation had been so great during the 2003 season, we assessed scab severity, finding no differences between airblast and the AARA sprayer treatments in that year.

The pattern of rainfall may have affected disease development. The precipitation for March $[132.1 \mathrm{~mm}$ (5.2 inches)], April [22.9 mm (0.9 inch)], and May [19.05 mm (0.75

Table 2. Mean insect damage, peel blemish, and incidence and severity of peach scab (Cladosporium carpophilum) and incidence of brown rot (Monilinia fructicola) were detected in peach field plots treated with the airblast or air assisted rotary atomizer (AARA) sprayer applications of pesticides during the 2000 through 2003 seasons.

\begin{tabular}{|c|c|c|c|c|}
\hline $\begin{array}{l}\text { Year and } \\
\text { treatment }\end{array}$ & $\begin{array}{c}\text { Insect } \\
\text { damage }\end{array}$ & $\begin{array}{c}\text { Peel } \\
\text { blemish }\end{array}$ & $\begin{array}{c}\text { Peach } \\
\text { scab }\end{array}$ & $\begin{array}{c}\text { Brown } \\
\text { rot }\end{array}$ \\
\hline \multicolumn{5}{|c|}{2000} \\
\hline Airblast at $100 \%^{\mathrm{z}}$ & $0 \mathrm{a}^{\mathrm{y}}$ & $0.4 \mathrm{a}$ & $0.3 \mathrm{~b}$ & $1.5 \mathrm{a}$ \\
\hline AARA at $80 \%$ & $0 \mathrm{a}$ & $0.3 \mathrm{~b}$ & $1.2 \mathrm{a}$ & $1.2 \mathrm{a}$ \\
\hline \multicolumn{5}{|c|}{2001} \\
\hline Airblast at $100 \%$ & $0.25 \mathrm{a}$ & $7.2 \mathrm{a}$ & $2.6 \mathrm{~b}$ & $0.4 \mathrm{a}$ \\
\hline AARA at $80 \%$ & $0.56 \mathrm{a}$ & $4.1 \mathrm{a}$ & $9.1 \mathrm{a}$ & $0.8 \mathrm{a}$ \\
\hline \multicolumn{5}{|c|}{2002} \\
\hline Airblast at $100 \%$ & $0.346 \mathrm{a}$ & $0.033 \mathrm{a}$ & $0.004 \mathrm{a}$ & $0 \mathrm{a}$ \\
\hline AARA at $80 \%$ & $0.496 \mathrm{a}$ & $0.038 \mathrm{a}$ & $0.154 \mathrm{a}$ & $0 \mathrm{a}$ \\
\hline AARA at $100 \%$ & $0.404 \mathrm{a}$ & $0.038 \mathrm{a}$ & $0.154 \mathrm{a}$ & $0 \mathrm{a}$ \\
\hline \multicolumn{5}{|c|}{2003} \\
\hline Airblast at $100 \%$ & $0.019 \mathrm{a}$ & $0.109 \mathrm{a}$ & $\begin{array}{l}0.262 \mathrm{a} \\
(1.39 \mathrm{a})\end{array}$ & $0.047 \mathrm{a}$ \\
\hline AARA at $100 \%$ & $0.016 \mathrm{a}$ & $0.059 \mathrm{a}$ & $\begin{array}{c}0.356 a \\
(1.58 a)^{x}\end{array}$ & $0.034 \mathrm{a}$ \\
\hline
\end{tabular}

inch)] of 2000 and for April [63.5 $\mathrm{mm}$ (2.5 inches)] and May [27.9 $\mathrm{mm}$ (1.1 inch)] of 2001 were below the 10-year average $[241.3 \mathrm{~mm}(9.5$ inches), $78.7 \mathrm{~mm}$ (3.1 inches), 58.4 $\mathrm{mm}$ (2.3 inches), and $106.7 \mathrm{~mm}(4.2$ inches) for March, April, May, and June, respectively] but March [243.8 $\mathrm{mm}$ (9.6 inches)] and June $[233.7 \mathrm{~cm}$ (9.2 inches)] 2001 precipitation was at or above the average. Scab incidence was greater for the AARA treatment in the 2000 and 2001 seasons, with scab being much greater in 2001 overall, than in 2000 (Table 2), when spring and early summer rains $[610 \mathrm{~mm}(24$ inches)] were above the 10-year average [483 mm (19 inches)]. With an increase of AARA rate to $100 \%$ in 2002 when scab incidence was low and the addition of a fourth spray head over each row for the AARA treatment before the 2003 spray season, when cool wet spring conditions favored higher scab incidences (Lawrence and Zehr, 1982), differences in scab incidence were remediated.

Spray coverage on mature peach trees using Rhodamine $\mathrm{B}$, at equal concentration for each treatment, as a coverage indicator was the same within the canopy when the sprayers
Table 3. Rhodamine B recovery was determined for the interior leaves and outer leaves from 10 peach tree canopies treated with airblast or air assisted rotary atomizer (AARA) sprayers used for applications of pesticides during the 2000 through 2003 seasons.

\begin{tabular}{llc}
\hline Treatments & Inside & Outside \\
\hline & $---\mu \mathrm{g} \cdot \mathrm{mL}^{-1}(\mathrm{ppm})--$ \\
Airblast & $32.2 \mathrm{a}^{\mathrm{z}}$ & $80 \mathrm{a}$ \\
AARA & $34.4 \mathrm{a}$ & $82.2 \mathrm{a}$ \\
\hline
\end{tabular}

${ }^{\mathrm{z}}$ Means followed by different letters in the same column are significantly different at $P \leq 0.05$ by Duncan's multiple-range test.

were compared (Table 3 ). Visual observation of differences in drift (Fig. 1), was supported by phosmet residue assays used as a test of degree of drift (Fig. 2). Phosmet residue was reduced $58.6 \%$ in the first adjacent row to the treatment row, $64.7 \%$ in the third row, and $93.3 \%$ in the fifth row (Fig. 2) with the AARA treatments conducted in the 'Sunprince' orchard after final harvest. Only a trace amount of phosmet was detected in the control leaves obtained 20 rows away from the treatment rows in the same orchard. The treatment row of the airblast sprayer initially 

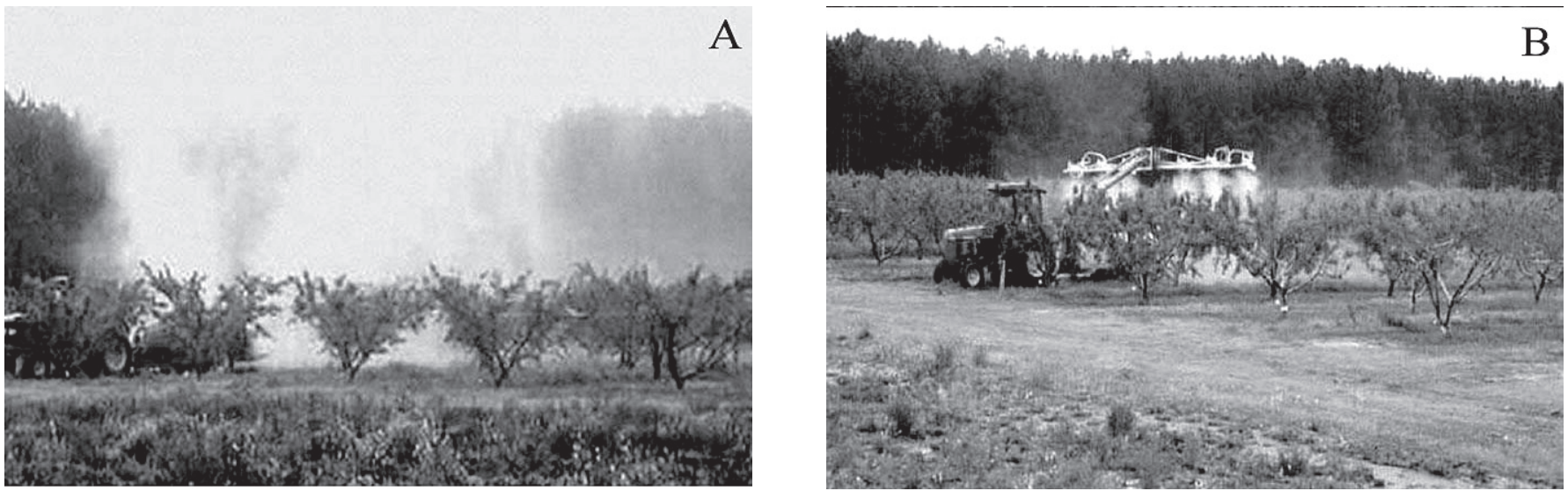

Fig. 1. Off-target pesticide movement (drift) was visually compared during pesticide application: A) Airblast sprayer, B) air assisted rotary atomizer (AARA) sprayer.

had $19 \%$ more phosmet than did the rotary atomizer sprayer. The calibrated application rate for the AARA sprayer was $80 \%$ of the airblast sprayer; thus the calculated and actual values agreed.

The airblast and AARA technologies tended to be similarly efficacious throughout the 4 years of the study for all pests and pathogens assessed except for scab. We found that the increase of fungicide for scab applications to the $100 \%$ level for the AARA sprayer, but maintaining the volume of pesticide application at $280.6 \mathrm{~L} \cdot \mathrm{ha}^{-1}$ was effective for scab management. The addition of a fourth spray head on each side of the boom reduced gaps between spray heads to increase efficiency of coverage but did not require more spray volume. Additionally, the AARA technology generally can be used to reduce the level of pesticide used to $80 \%$ with the exception of scab-suppressing materials, such as sulfur. There appear to be advantages in AARA technology relative to existing airblast sprayers: 1) reduced volume per hectare; 2 ) reduced fill-up times; 3 ) reduced spray time per unit area $\left[9.14 \mathrm{~min} \cdot \mathrm{ha}^{-1}\right.$ (3.7 $\mathrm{min} /$ acre $)$ for the AARA sprayer vs. $41.27 \mathrm{~min} \cdot \mathrm{ha}^{-1}$ (16.7 $\mathrm{min} /$ acre) for the airblast]; and 4) reduced overall cost for equipment, fuel, and labor. In practice, the industry moves through the orchard at speeds as great as $7.24 \mathrm{~km} \cdot \mathrm{h}^{-1}$ when using airblast pesticide application, rather than the recommended $3.2 \mathrm{~km} \cdot \mathrm{h}^{-1}$. Although the higher airblast speed is yet untested, the AARA technology applied at $8 \mathrm{~km} \cdot \mathrm{h}^{-1}$ may exceed efficacy of airblast application at these higher speeds. Because alternate row middles are traversed by the AARA sprayer, less orchard floor compaction (if the producer is careful to alter which rows

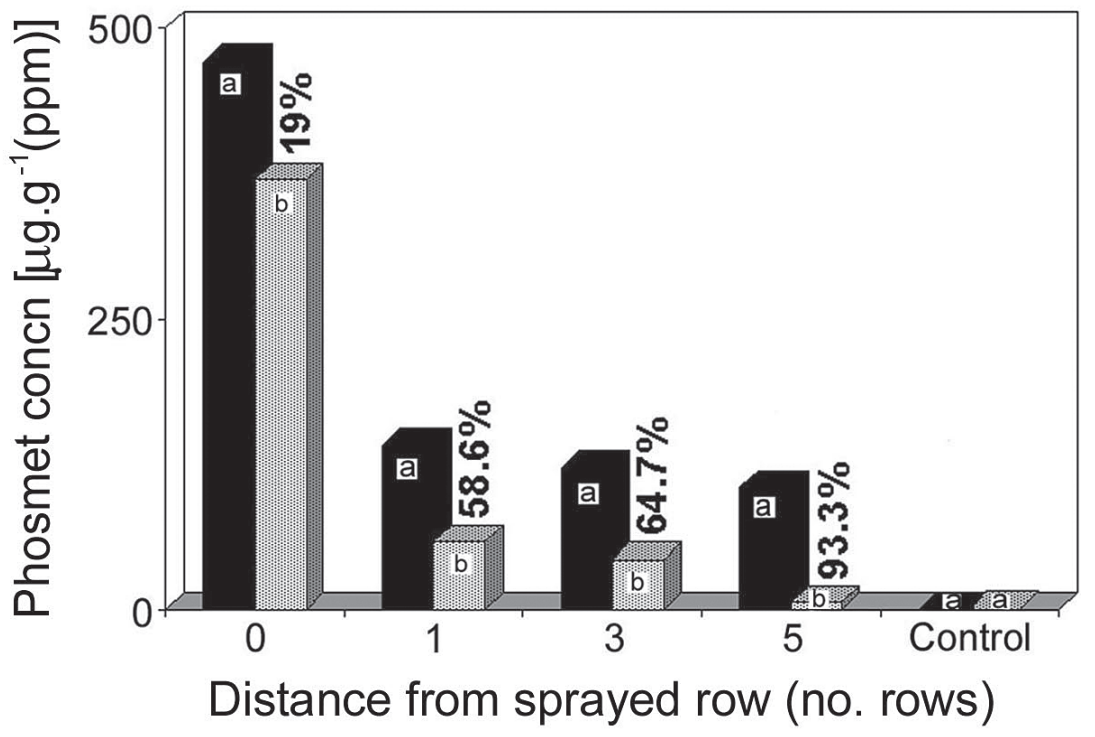

Fig. 2. Off-target pesticide (phosmet) movement (drift) from the airblast (solid bar) or air assisted rotary atomizer (AARA) (shaded bar) sprayers was determined at 1,3 , and 5 rows downwind from the treated row as phosmet residue level on leaf samples. AARA technology applied 20\% less phosmet to treatment row, percent on rows 1,3 , and 5 are differences between AARA and airblast sprayer residue detected. Means denoted with different letters for the same tree row (set of bars) are significantly different at $P \leq 0.05$ by Duncan's multiplerange test.

are traversed throughout the season) will likely occur and fewer fruit are bumped or knocked off as limbs sag with fruit maturity. This technology also reduces the amount of drift in the orchard, an important consideration, as the agricultural and urban sectors become contiguous.

\section{Literature cited}

Barrat, R.E., H.J. Retzer, and R.E. Adams. 1981. Comparison of spray droplet size, pesticide deposition, and drift with ultralow-volume, low-volume, and dilute pesticide application on apple. Plant Dis. 65(11):872-875.
Barrat, R.E., H.J. Retzer, and J.L. Mass. 1982. Ultra-low volume spraying: The next step in pest control. Fruit South. 6(2):7-10.

Cheng, G.W. and C.H. Crisosto. 1994. Development of dark discoloration on peach and nectarine (Prunus persica L. Batsch.) fruit in response to exogenous contamination. J. Amer. Soc. Hort. Sci. 119(3):529-533.

Chiba, M. 1974. Distribution of spray deposits in peach trees and number of leaves that constitute an adequate sample. J. Econ. Entomol. 67(4):529-634. 
Doruchouski, G. 1993. Use of tunnel sprayers in orchards and berry plantations, $\mathrm{p}$. 299-304. In: Proc. ANPP-BCPC 2nd Intl. Symp. Pesticide Application Techniques. Strasbourg, France, 22-24 Sept. 1993. Brit. Crop Protection Council, Thornton Heath, U.K.

Landers, A., W. Wilcox, G. English-Loeb, T. Martinson, and R. Dunst. 2000. Evaluation of a controlled droplet sprayer to control disease and insects on grapes in New York, p. 117-123. In: Rpt. of Eastern Viticult. Consortium. New York State Agr. Expt. Sta., Cornell Univ., Geneva.

Lawrence, E.G., Jr. and E.I. Zehr. 1982. Environmental effects on the development and dissemination of Cladosporium carpophilum on peach. Phytopathology 72(7):773-776.

Ledebuhr, M. 2000. Novel technology for over-the-row controlled droplet atomization spray application in tree and bush crops. Proc. Amer. Soc. Agr. Eng. Intl. Mtg. No. 1161. Milwaukee, Wis.

Ledebuhr, R.L., G.R. VanEe, R. Resmer, T. Forbush, and H.S. Potter. 1986. Field comparison of the effectiveness of air assisted rotary atomizers vs. conventional hydraulic nozzles for disease control and vine kill in potatoes, p. 107-119. In: B.F. Cargill (ed.). Engineering for potatoes. Amer. Soc. Agr. Eng., St. Joseph, Mich.
Little, T.M. and F.J. Hills. 1978. Agricultural experimentation: Design and analysis. Wiley, New York.

Littrell, R.J. and P.F. Bertrand. 1981. Effects of an abbreviated pecan disease control program on pecan scab disease increase and crop yield. Plant Dis. 72(1):27-32.

Peterson, D.L. and H.W. Hogmire. 1994. Tunnel sprayer for dwarf fruit trees. Trans. Amer. Soc. Agr. Eng. 37(3):709-715.

U.S. Dept. of Agriculture, Agricultural Marketing Service. 1995. U.S. standards for grades of peaches. 5 May 2003. < http://www.ams.usda.gov/standards / peaches.pdf>

U.S. Food and Drug Administration, Center for Food Safety and Applied Nutrition. 2002. Pesticide analytical manual. 5 May 2003. <http://vm.cfsan.fda.gov/ frf/ pamil.html $>$.

University of Georgia, Cooperative Extension Service. In: D.L. Horton, C. Gorsuch and D. Ritchie (eds.). 2003 Southern peach, nectarine and plum pest management and culture guide. Coop. Ext. Serv. Bul. 1171.

VanEe, G.R., R.L. Ledebuhr, E. Hanson, J. Hancock, and D.C. Ramsdell. 2000. Canopy development and spray deposition in highbush blueberry. HortTechnology $10(2): 353-359$. 